\title{
Investigation of formulation preparation of some plant extracts and determination of the effectiveness on Myzus persicae [(Sulzer, I776) (Hem.:Aphididae)]
}

\begin{abstract}
The extracts of Xanthium strumarium L., Tanacetum parthenium L. and Achillea wilhelmsii C. (Asteraceae) were prepared for testing against Myzus persicae Sulzer (Hemiptera: Aphididae). Formulations obtained from the extracts were subjected to quality control tests in the laboratory. According to the results of tests, preparations found successfully were separated and chosen for effectiveness studies on M. persicae. Effect of prepared formulations at three different doses were determined on $M$. persicae by using leaf dipping at the laboratory conditions. Fresh eggplant leaves were used for dipping bioassay experiments. As a result of the study the highest dose was found effective against the aphid. Effective dose and the two higher doses were used to examine effect on M. pesicae at the greenhouse conditions. The trial was established as randomized block design in greenhouse. The pepper plants were sprayed when the density of green peach aphid population 20 25 alive individual/leaf. Alive individuals were counted one, three and seven days after applications. All formulations showed the highest effect at $10 \mathrm{ml} / 1$ dose. Additionally, in the greenhouse conditions, the highest dose of $X$. strumarium caused phytotoxicity. The formulations of $A$. wilhelmsii and T. parthenium had high mortality rate. The formulations of $X$. strumarium showed the highest effect at dose $15 \mathrm{ml} / 1$.
\end{abstract}

Keywords: formulations, green peach aphid, insecticidal activity, plant extract
Volume 8 Issue 2 - 2020

\author{
Erdogan P,' Aksu P, Kilinc GE, ${ }^{2}$ Kahyaoglu \\ $\mathrm{M}^{3}{ }^{3}$ Babaroglu NE ${ }^{2}$ \\ 'Sivas University of Science and Technology, Turkey \\ 2Plant Protection Central Research Institute, Turkey \\ ${ }^{3}$ Agriculture and Chemical Industry Trade, Turkey
}

Correspondence: Erdogan P, Sivas University of Science and Technology, Faculty of Agricultural Sciences and Technology, Sivas,Turkey,Tel +90 346) 21913 98, Fax +90 346) 2191678 , Email pervinerdoan@sivas.edu.tr

Received: May 20, 2020 | Published: June 23, 2020

\section{Introduction}

The green peach aphid, Myzus persicae (Sulzer), is widely distributed all over the world. $M$. persicae can attain very high densities on young plant tissue, causing water stress, wilting and reduced growth rate of the plant. Prolonged aphid infestation can cause appreciable reduction in yield of root crops and foliage crops. Transmission of virus diseases is one of the most important impacts of $M$. persicae. Many authors consider that $M$. persicae is the most important plant virus vector in the world. Nymphs and adults of $M$. persicae are equally able to transport viruses. Additionally, intensive insecticide use against $M$. Persicae has caused resistance. ${ }^{2}$ In general, the use of chemical pesticides to control pests seen in agricultural production increased rapidly after World War II. This insecticide has resulted in the development of other issues. These included the development of insecticide resistance, the epidemics of main pests and secondary pests and the environmental pollution. Additionally, insecticide prices increased alternative methods for chemical compounds and natural pesticides to control pests have been researched. ${ }^{3}$ Studies on this subject have focused on biopesticides. Most of the studies are concentrated on plants. There is a long history of plant-based compounds to control pests. For example, the ancient Romans used plants containing insecticidal properties to control pests. ${ }^{4}$ It was thought that the choice of host made by phytophagous pests played an important role in secondary plant compounds. Most of plant compounds have antifeeding effect. ${ }^{5}$ Warthen $\&$ Morgan ${ }^{6}$ have listed more than 400 plants with antifeeding. Barnays \& Chapma $^{7}$ stated that plants have antifeeding and repellent effect property. Many studies have been conducted to search for alternative chemical pesticides in Turkey and studies are continuing. However, most of the studies have remained in the research stage and there are no applications to register biopesticides. Biopesticides have been needed to control pests especially in organic agriculture where chemical pesticides are not allowed to be used. All recorded biopesticides are overseas and have no biopesticides available for each product. Turkey has a very rich flora. It is important to study on biopesticides of plant origin, to evaluate the research results and their mode of action. The application of biopesticides obtained from local sources and plant origin substances are expected to fill the gap in the area of organic agriculture, integrated products and good agricultural practices. Biopesticides will significantly contribute to the national economy.

The aim of this study was to determine the insecticidal effects of the extracts obtained from T. parthenium, A. wilhelmsii and $X$. strumarium and the formulations prepared against $M$. persicae.

\section{Material and methods}

\section{Plants material}

Plants used in the study were gathered from three different the provinces during 2016 T. parthenium was collected from Cankiri province, A. wilhelmsii was collected Eskisehir province and $X$. strumarium was collected from Ankara province. Information of plants used in this study was given in Table 1.

\section{Preparing the extracts}

Plants and fruits collected for extract preparation were dried for 3-4 days without being exposed to sunlight and then ground with mill. Dried fruit and plants weighing $100 \mathrm{~g}$ were placed into the flasks, then ethanol (99.9\% purity) were added to flasks with 1:8 (w/v) ratio. 
The samples were extracted with a direct solvent under reflux in a water bath set at $60^{\circ} \mathrm{C}$ for two hours. At the end of two hours, the extract was filtered through a filter paper and then taken out of the flask balloon. Ethanol was added to the remaining part with the same ratio $1: 8(\mathrm{w} / \mathrm{v})$ and extracted for another two hours in a water bath set at $60^{\circ} \mathrm{C}$ for complete extraction of phenolic components. After two hours the second extract was filtered through a filter paper to the same glass balloon. The solvent of the extract was evaporated to dryness in a vacuum rotary evaporator at $60^{\circ} \mathrm{C} .{ }^{8}$ Three-five grams of extract were obtained from a total of $100 \mathrm{~g}$ of dry matter.

Table I Plants used in insecticidal bioassay on Myzus persicae Sulzer

\begin{tabular}{lll}
\hline Scientific name & Family name & Tissue used \\
\hline Tanacetum parthenium L & Asteracea & Flawers, leaves, buds \\
Achillea wilhelmsii C. & Asteracea & Flawers, leaves, buds \\
Xanthium strumarium L. & Asteracea & Fruits
\end{tabular}

\section{Formulation preparation of extracts}

The solubility of the extract with the appropriate solvents was determined based on the physicochemical properties of the components contained in the extract. The determination of the appropriate solvent was made by the method proposed by Flanagan ${ }^{9}$ According to the method, $1.20 \mathrm{~g}$ of extract was weighed into the test tube and 2 parts by volume of oil, water or appropriate solvents were added in the form of a maximum of $10 \mathrm{ml}$ of water. After each $2 \mathrm{ml}$ of solvent addition, the test tube was heated and stirred in a magnetic stirrer. If the amount of added solvent reached to $10 \mathrm{ml}$ and dissolution did not occur, then another solvent was tried by removing the former solvent from the experiments. In this way by using different vegetable oils (soybean, sesame, sunflower, corn, rapeseed, canola oil) as a solvent, the most suitable solvent was chosen to dissolve the extract and most suitable formulation type was selected. The extract was stirred at 800rpm in a vertical mixer together with a suitable solvent and co-formulates by considering the physical and chemical properties of the extract. The mixture was then stirred at 4500rpm for 1.5 hours in a high-speed vertical mixer until the fineness degree reached 10-20 microns and a homogeneous distribution was obtained. Thus, a homogeneous distribution of the insoluble components in the extract was achieved. The products taken into the resting tank were left for 24 hours and subjected to quality control analyzes.

\section{Quality control analysis}

Quality control tests were conducted as recommended by the Food and Agriculture Organization of the United Nations (FAO) and the World Health Organization (WHO) for Suspension concentrate (SC) formulation. ${ }^{10}$

\section{Physical analyzes}

Appropriate analyzes of the obtained Suspension Concentrate (SC) formulation were carried out in the Institute's laboratories using CIPAC analysis methods, considering the FAO Criteria. Aspect: The Suspension Concentrate (SC) formulation of the prepared solution was determined to be a heterogeneous suspension (viscous liquids) with a uniform color and a homogeneous structure when shaken. Once the product has been appropriately agitated, the bottom is checked with a rod and it is observed that it does not contain any layer or precipitate. This method has been assessed visually. ${ }^{10}$ Specific Gravity (Density):
The specific weight of the prepared formulation was determined by the digital dens meter (KYOTO DA-100) according to ASTM 4052 method in our laboratory. The decimeter was self-calibrating after a warm up period. An air sample was taken into the syringe and injected into the collar through the inlet of the sample-measuring chamber. The measurement button was turned on and the results were displayed on a screen. The results were recorded manually. Wet Sieve Test: The wet sieve test was performed according to CIPAC MT 185. Briefly, this method was conducted with $75 \mu \mathrm{m}$ sieve (Retch) and residue amount must be maximum 2\%. Suspension capability: The suspension capability test was conducted in according to CIPAC MT $184.250 \mathrm{ml}$ suspension was prepared with $0.5 \mathrm{~g}$ of sample. After standing for half an hour, the upper portion is withdrawn and the remaining $25 \mathrm{ml}$ is taken into pots and evaporated in water bath. Then the suspension capability was calculated.

\section{M. persicae culture}

Green peach leaflet culture was taken from Adana Biological Control Research Institute. M. persicae was reared on eggplant (Solanum melongena L.) leaf cultures in the laboratory at $25 \pm 1^{\circ} \mathrm{C}$ and under long daylight (18 light: 6 dark) and 65-70\% relative humidity. All the eggplant used in the experiment were grown in greenhouse.

\section{Dose-mortality tests}

Leaf-dipping method; A $3 \mathrm{~cm}$ in diameter disc was punched out from untreated eggplant leaves. These discs were then dipped into the test solutions (formulations prepared of extracts 1, 3, 5, 7 and $10 \mathrm{ml} /$ liter water) for one minute. The control disc was dipped in $0.01 \%$ Triton X-100 solution. Then leaves were left to dry for 30 minutes. The treated leaf discs were placed into petri dishes, which lined with moistened filter paper. Then 10 adult of M. persicae was introduced onto the treated discs in separate petri dishes. Same procedure was used for control. ${ }^{11}$ The experiment was replicated 10 times including control. Ten adults, three days old, were used for each petri dish. Data collection started after 1,3 , and 6 days by counting the number of living adults. The experiments were conducted in a climate chamber at $25 \pm 1{ }^{\circ} \mathrm{C}$ and under long daylight (18:6 light: dark).

\section{The experiments of greenhouse}

Effective doses $(10 \mathrm{ml} / \mathrm{L})$ and two top doses $(15,20 \mathrm{ml} / \mathrm{L})$ of the extract obtained from $T$. parthenium, A. wilhelmsii and X. strumarium plants. These doses were determined to be effective in laboratory conditions in the greenhouse in the Institute garden $\left(100 \mathrm{~m}^{2}\right)$. The pepper (Capsicum annuum L.) seedlings grown in the climate room for the trials were planted in the greenhouse on 27 July 2017. Five plants were planted in each plot. When the plants reached the 3-4 leaf stage, they were infected from the leaves of aphids grown in laboratory conditions to each plant with an infested leaf. When aphid population reached 20-25 live nymphs and adult/leaf, the extracts were applied on September 6, 2017. The trial greenhouse was established as randomized block design and replicated four times. Each plot consists of five pepper plants. When the plants were $20-25 \mathrm{~cm}$, they were infested with aphids. When the density of population reached 20-25 live individual/leaf, the plants were sprayed. In order to be able to represent the population by observing the parcels before each count, the density of the lower, middle and upper leaves was revised and the number of aphids on the leaf was estimated by determining the level at which the counting should be made and a class value was recorded. The 0-6 scale was used in the counts (Table 2). The counts were carried out 1, 3, 7 days after application. Neem Azal T/S was applied as positive control in greenhouse trials. 
Table 2 The 0-6 scale was used in counts on greenhouse experiment

\begin{tabular}{llll}
\hline \multirow{2}{*}{$\begin{array}{l}\text { Class } \\
\text { Infection degree) }\end{array}$} & \multicolumn{2}{l}{ Number of aphid } & \multirow{2}{*}{ Class mean } \\
\cline { 2 - 3 } & Lower limit & Upper limit & \\
\hline 0 & 0 & 0 & 0 \\
1 & 1 & 2 & 2 \\
2 & 3 & 10 & 7 \\
3 & 11 & 30 & 20 \\
4 & 31 & 100 & 70 \\
5 & 101 & 300 & 200 \\
\hline 6 & 301 & 1000 & 700 \\
\hline
\end{tabular}

\section{Statistical analysis}

The insecticidal effect was calculated according to Abbott. ${ }^{12}$ The obtained results were submitted to an analysis of variance and the mean values were compared by Duncan's test $(P=0.05)$ calculated by the program SPSS 20.6. For the statistical analysis, the formula Henderson-Tilton formula (13) was used for the greenhouse study.

\section{Results}

\section{Quality control analysis}

Suspended Concentrate (SC) formulations prepared from extracts were subjected to quality control analyzes such as appearance, specific gravity, suspension ability and fineness. Viscosity tests could not be carried out because samples could not be obtained in sufficient quantities. The formulation type SC of (Suspension Concentrate) the extract obtained from $A$. wilhelmsii had a brownish black liquid appearance. The specific weight (density) was $1,050 \mathrm{~g} / \mathrm{ml}$. Suspension ability (CIPAC MT 184) results are 100\%; (WHO) was found to pass completely through the 75-micron elec- trode. The formulation type of the extract obtained from T. parthenium was SC (Suspension Concentrate). Appearance is brownish liquid with specific gravity (density) value of $1,000 \mathrm{~g} / \mathrm{ml}$. Suspension ability (CIPAC MT 184) results are $100 \%$; It was determined that the depth grade test (WHO) passes completely through the 75-micron mesh. The formulation type of the extract obtained from $X$. strumarium was SC (Suspension Concentrate). Appearance was dark brownish liquid and specific weight (density) value is $1,070 \mathrm{~g} / \mathrm{ml}$. Suspension ability (CIPAC MT 184) results are $100 \%$; It was determined that the depth grade test (WHO) passes completely through the 75-micron mesh.

\section{Dose-mortality tests}

Plant extracts of $X$. strumarium, T. parthenium and A. wilhelmsii were prepared. Then the insecticidal effect of the formulations/ prepares were carried out on M. persicae by using method of bioassay under laboratory conditions. Leaf dipping data are shown in Table 3. The largest effect was at the highest dose $10 \%$ while the smallest effect was $1 \%$ in all extracts of plants. The effect increased depending on doses. The highest effect was the extract of T. parthenium, $X$. strumarium and $A$. wilhelmsii at concentration $10 \%$ respectively. Statistical analysis showed importance differences between the concentrations. Accordingly, all doses of the extracts formed different groups $(\mathrm{F}=1.469 ; \mathrm{P}=0.122)$.

Table 3 The insecticidal effects of obtained from three different plants on Myzus persicae Sulzer (Mean \pm SE)

\begin{tabular}{llll}
\hline $\begin{array}{c}\text { Doses }(\mathrm{ml} / \mathrm{L}) \\
\text { Effect }(\%)\end{array}$ & X.strumarium & A. wilhelmsii & T. parthenium \\
\hline 1 & $18.06 \pm 3.36 \mathrm{e}$ & $17.78 \pm 2.15 \mathrm{e}$ & $22.59 \pm 2.88 \mathrm{e}$ \\
3 & $25.93 \pm 4.92 \mathrm{~d}$ & $29.44 \pm 4.57 \mathrm{~d}$ & $37.96 \pm 2.15 \mathrm{~d}$ \\
5 & $35.00 \pm 3.07 \mathrm{c}$ & $47.59 \pm 4.10 \mathrm{c}$ & $59.44 \pm 3.67 \mathrm{c}$ \\
7 & $66.66 \pm 4.88 \mathrm{~b}$ & $66.66 \pm 3.23 \mathrm{~b}$ & $71.85 \pm 3.47 \mathrm{~b}$ \\
10 & & & \\
& $85.78 \pm 2.22 \mathrm{a}$ & $91.67 \pm 3.07 \mathrm{a}$ & $89.26 \pm 4.07 \mathrm{a}$ \\
\hline
\end{tabular}

*Means within rows followed by the same uppercase letter are not significantly different (Duncun's multiple range test)

\section{The experiments of greenhouse}

The extract of $X$. strumarium. A. wilhelmsii and T. parthenium had more than $75 \%$ effect in laboratory conditions. The results were given in Tables 4. The highest effect was determined in the Neem Azal $\mathrm{T} / \mathrm{S}$ preparation taken as the comparison of the plant extracts in the last count. Among plant extracts, the highest effect in X. strumarium extract was determined in the last count in the second dose. Counts could not be performed because phytotoxicity occurred at the highest dose of extract of $X$. strumarium. In the statistical analysis, both doses were found to be in the same group on the 3rd and 7th day counts. The effect of the lowest dose on T. parthenium extract was obtained on the 1st day. The highest dose was determined in the last counts. The highest effect in A. wilhelmsii was determined on the 7th day at the highest dose. It was determined that statistical analysis showed all doses were in the same group in the last census $(\mathrm{F}=25.149 ; \mathrm{P}=0.00)$. 
Table 4 The insecticidal effects of obtained from three different plants on Myzus persicae Sulzer (Mean \pm SE)

\begin{tabular}{|c|c|c|c|c|}
\hline \multirow{3}{*}{ Treatments } & \multirow{3}{*}{$\begin{array}{l}\text { Doses } \\
(\mathrm{ml} / \mathrm{l})\end{array}$} & \multicolumn{3}{|l|}{ Count times } \\
\hline & & $\left.\right|^{\text {st }}$ day $(|5.9 .20| 7)$ & $3^{\text {rd }}$ day $(17.9 .20 \mid 7)$ & $7^{\text {th }}$ day $(24.9 .2017)$ \\
\hline & & \multicolumn{3}{|l|}{ Effect (\%) } \\
\hline \multirow{4}{*}{ T. parthenium } & 10 & $35.03 \pm 2.38 b^{* *} C^{*}$ & $48.81 \pm 1.01$ с B & $64.62 \pm 0.93 \mathrm{cA}$ \\
\hline & 15 & $53.72 \pm 2.86$ a C & $68.7 I \pm I .68$ b B & $83.15 \pm 0.10 \mathrm{cA}$ \\
\hline & 20 & $60.58 \pm 2.87 \mathrm{a} C$ & $76.50 \pm 1.84$ a B & $84.57 \pm 0.62$ a $A$ \\
\hline & 10 & $34.97 \pm 2.33$ с C & $50.01 \pm 0.93$ с B & $61.36 \pm 1.10 \mathrm{bA}$ \\
\hline \multirow{2}{*}{ X. strumarium } & 15 & $55.5 \mathrm{I} \pm 4.59$ b B & $64.92 \pm 1.67$ b B & $85.69 \pm 3.21$ a A \\
\hline & 20 & $67.95 \pm 1.29$ a B & $78.03 \pm 1.18$ a A & Phytotoxicity \\
\hline \multirow{3}{*}{ A. wilhelmsii } & 10 & $37.04 \pm 2.85$ с В & $46.30 \pm 6.58$ с В & $64.04 \pm 2.41 \mathrm{cA}$ \\
\hline & 15 & $65.20 \pm 1.36$ b B & $74.48 \pm 0.3 \mathrm{I} b \mathrm{bA}$ & $72.92 \pm 6.25 \mathrm{~b} \mathrm{~A}$ \\
\hline & 20 & $61.81 \pm 2.95$ a A & $74.49 \pm 2.90$ a A & $81.60 \pm 2.97$ a A \\
\hline Neem Azal T/S*** & 5 & $65.97 \pm 1.09 \mathrm{C}$ & $77.69 \pm 1.32 \mathrm{~B}$ & $92.8 \mathrm{I} \pm 2.26 \mathrm{~A}$ \\
\hline
\end{tabular}

*Means within rows followed by the same uppercase letter are not significantly different (Duncuns's multiple range test)

** Means within column followed by the same lowercase are not significantly different (Duncuns's multiple range test)

****Positive control

\section{Discussion}

The extracts were obtained from T. parthenium, X. strumarium and A. wilhelmsii plants and their formulation was first prepared, and their effect was first tested on $M$. persicae in the greenhouse conditions. The extracts were highly insecticidal effective on $M$. persicae. It was reported that the extracts of $T$. parthenium showed the highest insecticidal effect both in the laboratory and in the greenhouse on $M$. persicae. It was revealed that extracts of $T$. parthenium had the highest mortality effect on $M$. persicae the highest concentration $(12 \%) .{ }^{14}$ In another study. Erdogan \& Yildirım. ${ }^{15}$ reported that the extract $T$. parthenium had different effects such as high mortality, or oviposition deterrent on Tetranychus urticae Koch. (Arachnida:Tetranychidae). Jain \& Kulkarni revealed ${ }^{16}$ that the extracts of T. parthenium had antinociceptive and anti-inflammatory effects without altering the normal behavior of the mice and rats. Other studies have been made on species belonging to Asteraceae family. For example, the extract of Tanaceum vulgare L. showed the postingestional deterrent activity. The extract of Tanacetum mucroniferum, Chrysanthemum segetum and Artemisia vulgaris showed antifeedant effects on Spodoptera littoralis (Boisduval) (Lepidoptera: Noctuidae). ${ }^{17}$ Yadav \& Patel ${ }^{18}$ reported that the crude aqueous extract obtained from Parthenium hysterophorus had insecticidal and repellent properties on M. persicae and Brevicoryne brassicae (L.). Additionally, Erdogan \& Yıldırım ${ }^{14}$ reported that the extract of $T$. parthenium had strong insecticidal effect on $M$. persicae. The extract of pyrethrum consists of many organic substances including pirethrin, which exhibited insecticidal properties. Pirethrin has been used as insecticide since ancient times. Particularly, pirethrin was used to control Thrips spp. and Aphids spp. Also. pirethrin has been used in public health programs ${ }^{19}$ According to a recent study, Tanacetum spp contain a large number of natural products. However, the active components may include one or more of the sesquiterpene lactones including parthenolide. Other potentially active constituents include flavonoid glycosides and pinenes. It is believed that the parthenolide may independently or in combination with other substances caused insecticidal action against $M$. persicae..$^{20}$

Xanthium strumarium has many substances which showing bioactive properties and these compounds have insecticidal effect. ${ }^{21,22}$ There are many of studies on extract of $X$. strumarium. For example Malik et al revealed that the essential oil obtained from $X$. strumarium caused mortality the larva of Thylenculus semipenetrans. In addition, the extract of $X$. strumarium fruits had repellent effect on Leptinotarsa decemlineata Say (Col.: Chrysomelidae) adults and larvae. ${ }^{23}$ It was reported that the extract of $X$. strumarium fruits prolonged larva and pupae instar causing high mortality rate of larvae and pupae during stage and oviposition deterrent on $L$. decemlineata. ${ }^{24,25}$ Roy et $\mathrm{al}^{26}$ reported that $X$. strumarium extract had effects on mortality, repellency, fecundity and adult emergence of Callosobruchus chinensis L. (Col.: Bruchidae). They also determined that the highest percentage of adult emergence inhibition of C. chinensis. Erdogan \& Yıldırım ${ }^{14}$ reported that $X$. strumarium extract was insecticidal efficacy on $M$. persicae. Uskutoğlu et $\mathrm{al}^{27}$ reported that the extract of $X$. strumarium might be used as insecticides. Xanthium strumarium consists of carboxyatractyloside and Xanthatin substances. Carboxyatractyloside causes hypoglycemia in animals that consume it probably because it causes uncoupling of oxidative phosphorylation. ${ }^{28,29}$ In our study, we postulate that carboxyatractyloside and Xanthatin substances caused the insecticidal effect although the effective substance of extracts has been not determined. The extract of A. wilhelmsii (C) had the highest acaricidal and insecticidal effect on T. urticae, $L$. decemlineata. ${ }^{30-32}$ Khani \& Asghari ${ }^{33}$ reported that the essential oil of A. wilhelmsii showed the strong insecticidal effect on Tribolium castaneum Herbst (Coleoptera:Tenebrionidae) and Callosobruchus maculatus F. (Coleoptera: Bruchidae). The extract of A. wilhelmsii caused the highest mortality on T. urticae. ${ }^{34}$ It has been reported that the extract of $A$. wilhelmsii had larvicidal effect on $2^{\text {nd }} \cdot 3^{\text {rd }}$ and $4^{\text {th }}$ instar larvae of Thaumetopoea piyocampa (Dennis\&Schiffermuller) 
(Lep.:Thaumetopoeidae). ${ }^{35}$ A. wilhelmsii has several effects including anti-spasmodic, anti-inflammatory, diuretic and diaphoretic have been used for treatment of hemorrhage, pneumonia and rheumatic pain. ${ }^{36,37}$ This plant contains chemical components including flavonoids, cineol, alkaloids (achilleine), borneol, camphor, $\alpha$ - and $\beta$-pinen, caryophyllene, rutin, thujene, sesquiterpenoids and monoterpenoids. ${ }^{38}$ Several plants have been found to contain bioactive compounds with a variety of biological actions against insects, including repellent, antifeedant, anti-ovipositional toxic, chemosterilant and growth regulatory activities. ${ }^{39}$ Therefore, botanical insecticides have long been recommended as attractive alternatives to synthetic chemical insecticides for pest management because these chemicals pose little threat to the environment or to human health. ${ }^{40}$ There are many studies on the effect of plant extracts on insects, but there are few of formulated product from obtained plants. ${ }^{41}$ The most important of these plants is Azadirachta indica (A. Juss). ${ }^{42}$ Currently, there are preparations named Margosan-O, Azatin, Bioneem, Neemguard and Neem Azal T / $\mathrm{S}$ developed from extract of $A$. indica. The other commercial products are the tea tree oil obtained from Melaleuca alternifolia. Maiden \& Betche, Cheel) named Gamma-T-Ol and Fungatol. Our study is the first that records the preparation of the formulations of plant extracts. The insecticidal effect of these formulations on $M$. persicae was determined in greenhouse conditions.

\section{Conclusion}

The formulated extracts of $T$. parthenium, $X$. strumarium and $A$. wilhelmsii had the highest insecticidal effect on $M$. persicae. The studies on extraction and preparation of the formulation were carried out on a pilot scale in the laboratory conditions. Large-scale production facilities would be required produce the formulations and to subject them to quality control tests. More research is required to develop this initial study further.

\section{Acknowledgments}

We would like to thank to General Directorate of Agricultural Research and Policies for financial support of this work. Project No: TAGEM-BS-12 / 09-07/01-14.

\section{Conflicts of interest}

The authors declare that they have no competing interests.

\section{References}

1. Petitt FL, Smilowitz Z. Green peach aphid feeding damage to potato in various plant growth stages. Journal Economic Entomology. 1982;75:431-435.

2. Namba R, Sylvester ES.Transmission of cauliflower mosaic virus by the green peach, turnip, cabbage and pea aphids. Journal Economic Entomology. 1981;74: 546-551.

3. Gren MB, Heidin PA. Allelopathic agents; Pests; Insect-plant relationships; Congresses; Biological control, Natural Resistance of Plants to Pests, Roles of Allelochemicals. Journal of the American Chemical Society. 1986;296:243.

4. Smith AE. Secoy DM. Use of Plants in Control of Agriculture and Domestic Pests. Journal Agricutural Food and Chemistry. 1975;23:1050.

5. Jacobson M. Plants Insects and man their interrelationships. Economic Botany. 1982;36:346-354.

6. Warthen JD, Morgan ED. Insect feeding deterrents. In: Morgan ED, Mandava NB, editoes. CRC handbook of natural pesticides.VI: insect attractants and repellents. Florida, USA. CRC Press Boca Raton. 1990:23134
7. Barnays E, Chapman R. Deterrent chemicals as a basis of oligophagy in Locusta migratoria (L). Ecological Entomology. 1977; 2:1-18.

8. Gur E. Oregano Ekstraktlarının Rafine Zeytinyağındaki Antioksidatif Etkilerinin İncelenmesi. 1995.

9. Flanagan J. Principles of pesticide formulation Industrial production and formulation of pesticides indevoloping countrie. General principles and formulation of pesticides. New York, United Nations. 1995;(6):75-122.

10. Anonymous. Manual on development and use of FAO and WHO specifications for pesticides 1 st \& 3rd edn. 2016

11. Bollhalder F, Zuber M. Neem Azal T/S against Myzus persicae Practice Oriented Results on Use and Production of Neem Ingredients and Pheromones. Proceedings at the 5th Workshop, Wetzlar Germany. Jan 22 25. 1997: 141-145p.

12. Abbott WS. A method of computing the effectiveness of an insecticide. Journal of Economic Entomology.1925;18(2):265-267.

13. Digillio V, Cristofora M, Marchini DD, et al. Effects of a neem compound on the fecunditiy and longevity of Cerstitis capitata(Diptera:Tephritidae). Journal Economic Entomology. 1996;92(1)76:82.

14. Erdogan P, Yildırım A. Insecticidal Activity of Three Different Plant Extracts on the Green Peach Aphid [(Myzus persicae Sulzer) (Hemiptera: Aphididae)]. Journal of the Entomological Research Society. 2016;18(1):27-35.

15. Erdoğan P, Yıldırım A. İki Farklı Bitki Ekstraktının Yesil seftali yaprakbiti [(Myzus persicae Sulzer) (Homoptera: Aphididae)]'ne İnsektisit Etkileri Uzerinde Arastirmalar. Bitki Koruma Bulteni. 2013;53(1):33-42.

16. Jain NK, Kulkarni SK. Antinociceptive and Anti-Inflammatory Effects of Tanacetum Parthenium L. Extract in Mice and Rats. Journal Ethnopharmacol. 1999;15;68(1-3):251-259.

17. Karakoc OC, Gökçe A. Farklı bitki ekstraktlarının Spodoptera littoralis (Lepidoptera: Noctuidae) üzerinde beslenme engelleyici ve mide zehiri etkileri. Türkiye Entomoloji Dergisi. 2013;37(1):73-80.

18. Yadav S, Patel S. Insecticidal and repellent activity of some plant extracts against Myzus persicae (Sulzer) and Brevicorne brassicae (Lineaus). Journal of Entomology and Zoology Studies. 2017;5(2):1434-1439.

19. Arslan N, Yılmaz G. Pestisit kirliliğinin azaltılmasında bitkisel bir kaynak pireotu (Pyrethrum sp.) türleri. Ekoloji. .1993;3-6.

20. Pareek A, Manish S, Rathore GS, et al. Feverfew (Tanacetum parthenium L): A systematic review. Pharmacognosy Revie. 2011;5(9):103-110.

21. Alpaslan P. Xanthium L. Bitkisinde Biyolojik AktifBilesiklerin İzolasyonu, Yapıların Aydınlatılması ve Asetilkolinesteraz ve Butirilkolinesteraz İnhibisyon Aktivitelerinin İncelenmesi. Trakya Üniversitesi Fen Bilimleri Enstitüs. 2013;129.

22. Sarı AO, Oguz B, Bilgic A, et al. Ege ve Güney Marmara Bölgelerinde Halk İlacı Olarak Kullanılan Bitkiler. Anadolu Journal of AARI. 2013;20(2):1-21.

23. Cetinsoy S, Tamer A, Aydemir M, et al. Investigations on repellent and insecticidal effects of Xanthium strumarium $\mathrm{L}$ on Colorado potato beetle Leptinotrsa decemlineata Say (Col: Chrysomelidae). Turkish Journal of Agriculture and Forestry. 1995;22:543-552.

24. Erdogan P, Toros S. Investigations on the effects of Xanthium strumarium L. extracts on Colorado potato betle [(Leptinotarsa decemlineata Say. Col.: Chrysomelidae)]. Munis Entomology\&Zoology. 2013;2(2):423-432.

25. Erdogan P, Saltan G, Sever B, et al. Domuz pitrağı (Xanthium strumarium L.) Ekstraktının İki noktalı kırmızı örümcek (Tetranychus urticae Koch (Arachnida: Acarina. F. Tetranychidae) ‘e Etkisi Uzerinde Arastırmalar 1. GAP Organik Tarım Kongresi Bildirileri Kitabi. 2009:174-180.

26. Roy B, Jalal S, Sarker BC, et al. Evaluation of Insecticidal Activities of Common Cocklebur Fruit Extract agains Pulse Beetle Collosubruchus chinensis (Coleoptera: Bruchidae). Korean Journal Applied Entomology. $2012 \cdot 51(4): 325-329$. 
27. Uskutoglu C, Cesur TC, Senkalli BC, et al. Pitrak (Xanthium strumarium L.) Bitkisinin Farklı Açılardan Değerlendirilmesi. Anadolu Ege Tarımsal Araştırma Enstitüsü Dergisi. 2018;28(1):113-11.

28. Scherer R, Duarte M CT, Catharino RR, et al. Xanthium strumarium L. antimicrobial activity and carboxyatractyloside analysis through electrospray ionization mass spectrometry. Revista Brassileira de Plantas Medicinals. 2009;11(2).

29. Harada AK, Sakata H, Ina K, et al. Isolation and Identification of Xanthatin as an anti-attaching Repellent against Blue mussel. Agricultural and Biological Chemistry. 1985;4961987-1988.

30. Erdogan P, Yildirim A, Saltan G, et al. Civanperçemi, Achillea wilhelmsii C) Ekstraktının İki noktalı kırmızı örümcek [Tetranychus urticae Koch. (Arachnida: Tetranychidae)]'e Etkisi Uzerinde Arastirmalar. 2010;70-75.

31. Cakır A, Ozer H, Aydın T, et al. Phytotoxic and Insecticidal Properties Essential Oils and Extracts of Four Achilla Species ACG. Record of Natural Products. 2016;10(2):154-167.

32. Khani A, Asghari J. Insecticide activity of essential oils of Mentha longifolia Pulicaria gnaphalodes and Achillea wilhelmsii against two stored product pests the flour beetle Tribolium castaneum and the cowpea weevil Callosobruchus maculatus. Journal of Insect Science. 2012:12(1).

33. Erdogan P, Yildirim A, Sever B, et al. Investigations on the Effects of Five Different Plant Extracts on the Two-Spotted Mite, Tetranychus urticae Koch (Arachnida: Tetranychidae). Hindawi Publishing Corporation Psyche. 2012:5
34. Kesdek M, Kordali S, Coban K, et al. Larvacidal effect of some plant extracts on the pine processionary moth Thaumetopoed pitypcampa(Denis,Schiffermuller) in laboratory. Acta Scientarium Polonorum Horticulture. 2014;13(5):145-162.

35. Amjad L, Torki M, Yazdani F, et al. A Comparative Analysis of Chemical Composition of Two Ecotypes of Achillea wilhelmsii in Iran. Advances in Bioresearch. 2016;6(4):148-151.

36. Saeidnia S, Gohari AR, Dezfuli-Mokhber N, et al. A review on phytochemistry and medicinal properties of the genus Achilla. Daru. 2011;19:173-186.

37. Majd PJH, Grantham HJM. Neuronal response in Alzheimer's and Parkinson's disease: the effect of toxic proteins on intracellular pathways. BMC Neurosci. 2015

38. Singh RN, Saratchandra B. The development of botanical products with special reference to seri-ecosystem. Caspian Journal Environmental Sciences. 2005;3(1):1-8.

39. Isman MB. Botanical insecticides deterrnts and repellents in modern agriculture and increasingly regulated. World Annual Review Entomolog, 2006;51:45-56.

40. Rembold DH, Sharma GK, Czoppelt CH, et al. Azadirachtin A potent insect growth regulator of plant origin. Zeitschrift für Angewandte Entomologie. 1982;9:12-17. 